\title{
Dot-blot hybridization and RT-PCR detection of extra small virus (XSV) associated with white tail disease of prawn Macrobrachium rosenbergii
}

\author{
Joannes Sri Widada*, Véronique Richard, Zhengli Shi, Dong Qian, Jean-Robert Bonami
}

Pathogens and Immunity, CNRS, Université Montpellier II, cc 080, Place Eugène Bataillon, 34095 Montpellier Cedex 5, France

\begin{abstract}
The availability of specific and reliable detection methods is essential for monitoring the health status of farmed species, particularly for viral diseases. Extra small virus (XSV), a virus-like particle, is associated with Macrobrachium rosenbergii Noda virus (MrNV) in white tail disease (WTD) of $M$. rosenbergii. We developed 2 genome-based detection methods for the identification of XSV, namely dot-blot hybridization and a single-step RT-PCR. Detection limits were established and are ca. $2.5 \mathrm{pg}$ and $5 \mathrm{fg}$ of viral RNA for dot-blot hybridization and RT-PCR, respectively. Application of the methods to field samples indicated that some animals positively diagnosed with $\mathrm{MrNV}$ did not contain XSV, at least within the detection limit of the methodology. This raises the question of the actual role of XSV and its interactions with $M r N V$ in WTD of $M$. rosenbergii.
\end{abstract}

KEY WORDS: Diagnostic tools $\cdot$ Dot-blot hybridization $\cdot \mathrm{XSV} \cdot \mathrm{MrNV} \cdot$ Macrobrachium rosenbergii $\cdot$ RT-PCR Resale or republication not permitted without written consent of the publisher

\section{INTRODUCTION}

Among the emerging diseases encountered in industrial aquaculture, viral diseases are the most difficult to control. They constitute the major health problem and a limiting factor in shrimp farming, resulting in important production losses during acute epizootics. Preventive measures, including early diagnosis done in hatcheries, are the sole means to prevent disease outbreaks.

The giant freshwater prawn Macrobrachium rosenbergii is an economically important farmed crustacean. White tail disease (WTD), a disease affecting M. rosenbergii, was first observed in Guadeloupe island in 1995 and then in Martinique island (French West Indies) (Arcier et al. 1999), later in Taiwan (Tung et al. 1999) and the People's Republic of China (Qian et al. 2003), and most recently in India (S. Hameed pers. comm.). WTD appeared to spread rapidly, resulting in important economic losses due to the high mortalities in farmed M. rosenbergii. The pathogenic agent of WTD was found to be a virus which was subsequently named M. rosenbergii Noda virus ( $M r N V)$ (Arcier et al. 1999). There are few known pathogenic viruses of Macrobrachium rosenbergii. It has since been reported that $M r N V$ is associated with a small viruslike particle, called extra small virus (XSV) (Qian et al. 2003). XSV is icosahedral in shape and $15 \mathrm{~nm}$ in diameter. Its genome is currently under investigation in our laboratory. It consists of 1 linear single-stranded RNA, the sequencing of which is now completed (GenBank Accession Number AY247793).

Due to the severity of WTD, there is an urgent need for reliable detection methods for the pathogenic agents involved. The disease is currently diagnosed by the whitish coloration of the prawn tail. The diagnosis is not accurate as this symptom is not characteristic. Moreover, as 2 viruses are most probably involved, it is important to have specific detection methods for each. 
A sandwich enzyme-linked immunosorbent assay (SELISA) was developed recently for $\mathrm{MrNV}$ diagnosis (Romestand \& Bonami 2003).

In this paper we describe 2 genome-based detection methods for specific identification of XSV. The methods we developed are specific and reliable and were applied to field samples.

\section{MATERIALS AND METHODS}

Prawn specimens. Whole larvae and post-larvae (PL) (size 3 to $7 \mathrm{~mm}$ ) and heads of adult prawns (size 100 to $150 \mathrm{~mm}$ ) were obtained from hatcheries in Guadeloupe and Martinique (French West Indies). For the validation, PL were also collected from hatcheries in China. Samples were kept frozen or in $75 \%$ ethanol. Prawns with WTD were sampled from natural disease outbreaks and diagnosed by the whitish coloration of their tail. Negative controls were obtained from an unaffected hatchery.

Extraction of viral RNA. Viral particles were purified from tissue extracts of prawns with WTD by centrifugation in sucrose gradient then in $\mathrm{CsCl}$ gradient and finally concentrated by centrifugation through a sucrose cushion, as previously described (Romestand \& Bonami 2002). This technique also allowed the separation of XSV from $M r N V$. Viral RNA was extracted by a combination of phenol-chloroform treatment, then precipitated with ethanol. RNA was then dissolved in DEPC (diethylpyrocarbonate)-treated water and the amount of nucleic acid was quantified by measuring absorbance at $260 \mathrm{~nm}$.

Total RNA purification. Tissue extract was obtained by homogenizing approximately $75 \mathrm{mg}$ of tissue in $150 \mu \mathrm{TN}$ buffer $(20 \mathrm{mM}$ Tris- $\mathrm{HCl}, 0.4 \mathrm{M} \mathrm{NaCl}$, $\mathrm{pH}$ 7.4). The homogenate was then centrifuged at $12000 \times g$ (bench minicentrifuge) for $15 \mathrm{~min}$. Total RNA was extracted from the supernatant using Trizol reagent (Life Technologies) as specified by the manufacturer. Briefly, $1 \mathrm{ml}$ of Trizol reagent was added to the supernatant and homogenized. After $5 \mathrm{~min}$ incubation at room temperature, $0.2 \mathrm{ml}$ chloroform was added. The sample was vigorously shaken for 2 to $3 \mathrm{~min}$ at room temperature, then centrifuged at $12000 \times g$ for $15 \mathrm{~min}$ at room temperature. RNA was precipitated from the aqueous phase with isopropanol, washed with $75 \%$ ethanol, and dissolved in $50 \mu \mathrm{l}$ of Tris-EDTA (10 mM Tris-HCl, 1 mM EDTA, pH 7.5).

Dot-blot hybridization. The probe used was a DNA fragment derived from the XSV genome, cloned in pCR2.1-TOPO. It was labeled with DIG (digoxigenin)labeled nucleotide by PCR, using a PCR DIG-labeling mix (Roche), and Primer Pair XS-1/XS-5 (see next section). The conditions of PCR were those used in RT-PCR (see next section), except that the reverse transcription step was omitted.

Hybridization was carried out using RNA either obtained from a viral preparation or from tissues. Samples were denatured in MOPS buffer (2 mM MOPS [3-N-morpholino-2-hydroxpropane sulfonic acid], $5 \mathrm{mM}$ sodium acetate, $1 \mathrm{mM}$ EDTA, $\mathrm{pH} 7.0$ ), $50 \%$ formamide and $2 \mathrm{M}$ formaldehyde, at $65^{\circ} \mathrm{C}$ for $5 \mathrm{~min}$, and then chilled in ice. When required, successive 10 -fold dilutions were prepared in denaturing buffer. One $\mu$ of each sample was then dot-blotted in duplicate on Hybond-N membrane (Amersham-Pharmacia). The membrane was dried at $50^{\circ} \mathrm{C}$ for $1 \mathrm{~h}$, then cross-linked under UV for $3 \mathrm{~min}$. Pre-hybridization was carried out at $42^{\circ} \mathrm{C}$ for 3 to $4 \mathrm{~h}$ in $50 \%$ formamide, $2 \times$ saline sodium citrate (SSC), $50 \mathrm{mM}$ sodium phosphate, $2 \%$ blocking reagent, $0.1 \%$ sodium sarkosyl, and $7 \%$ sodium dodecyl sulphate (SDS). Hybridization was performed overnight at $42^{\circ} \mathrm{C}$ by adding 5 to $25 \mathrm{ng} \mathrm{ml}^{-1}$ of denatured labeled probe. The membrane was washed twice with $2 \times \mathrm{SSC}$, with $0.1 \% \mathrm{SDS}$ for $15 \mathrm{~min}$ at room temperature, then twice with $0.5 \times \mathrm{SSC}$, with $0.1 \% \operatorname{SDS}$ for $15 \mathrm{~min}$ at $68^{\circ} \mathrm{C}$.

Detection was done as follows, and all the successive steps were carried out at room temperature: the membrane was first washed in Washing Buffer I (100 mM maleic acid, $150 \mathrm{mM} \mathrm{NaCl}, \mathrm{pH} 7.5,0.3 \%$ Tween 20) for 1 to $3 \mathrm{~min}$, blocked with blocking solution (100 mM maleic acid, $150 \mathrm{mM} \mathrm{NaCl}, \mathrm{pH} 7.5,1 \%$ blocking reagent) for $1 \mathrm{~h}$, then washed twice with Washing Buffer I for $15 \mathrm{~min}$, and finally washed once more with Washing Buffer II (100 mM Tris-HCl, pH 9.5, 100 mM $\mathrm{NaCl}, 50 \mathrm{mM} \mathrm{MgCl}_{2}$ ) for $5 \mathrm{~min}$. The presence of hybridized probes was revealed by incubating the membrane in $2 \mathrm{ml}$ of Buffer II, containing $9 \mu \mathrm{l}$ nitroblue tetrazolium (NBT) and $7 \mu \mathrm{l}$-phosphate solution, in a dark room for a minimum of $2 \mathrm{~h}$ or overnight.

RT-PCR. Reverse transcription and amplification were carried out using the 'Titan One Tube RT-PCR system' (Roche). Four pairs of primers were designed from the sequence data of an XSV isolate from Martinique (French West Indies) (GenBank Accession Number AY247793) (the position of the primers in the genome is indicated in brackets) and were as follows: upstream primers, XS-1 GGAGAACCATGAGATCACG (88-106); XS-3 GGACAATGGG-ATCTAATCTC (121-140); downstream primers, XS-5 CTGCTCATTACTGTTCGGAGTC (594-573); XS-6 GGATCTTTAGCAGTGGTAGTG (538-518). Primer Pair 1 (XS1/XS-5) and Primer Pair 2 (XS-3/XS-6) give rise to DNA fragments of ca. 0.5 and $0.4 \mathrm{~kb}$, respectively. Reactions were performed in $25 \mu \mathrm{l}$ RT-PCR buffer containing 12.5 pmole of each primer, and varying amounts of RNA template, using the following steps: reverse transcription at $52^{\circ} \mathrm{C}$ for $30 \mathrm{~min}$; denaturation 
at $94^{\circ} \mathrm{C}$ for $2 \mathrm{~min}$, followed by 25 cycles of denaturation at $94^{\circ} \mathrm{C}$ for $30 \mathrm{~s}$; annealing at $52^{\circ} \mathrm{C}$ for $30 \mathrm{~s}$; and elongation at $68^{\circ} \mathrm{C}$ for $1 \mathrm{~min}$; ending with an additional elongation step of $10 \mathrm{~min}$ at $68^{\circ} \mathrm{C}$. Half of each reaction product was analyzed by electrophoresis on a $0.8 \%$ agarose gel.

\section{RESULTS AND DISCUSSION}

\section{Dot-blot hybridization}

Dot-blot hybridization constitutes an easy technique which is currently used for pathogen detection. In order to establish its suitability and sensitivity, hybridization was first carried out using purified viral RNA. The method was then applied to total RNA extracted from tissues.

Six successive 10-fold dilutions were tested, from $2.5 \mathrm{ng}$ to $25 \mathrm{fg}$ of viral RNA. Hybridization results show that a positive response was still observed with $2.5 \mathrm{pg}$ of viral RNA (Fig. 1a).

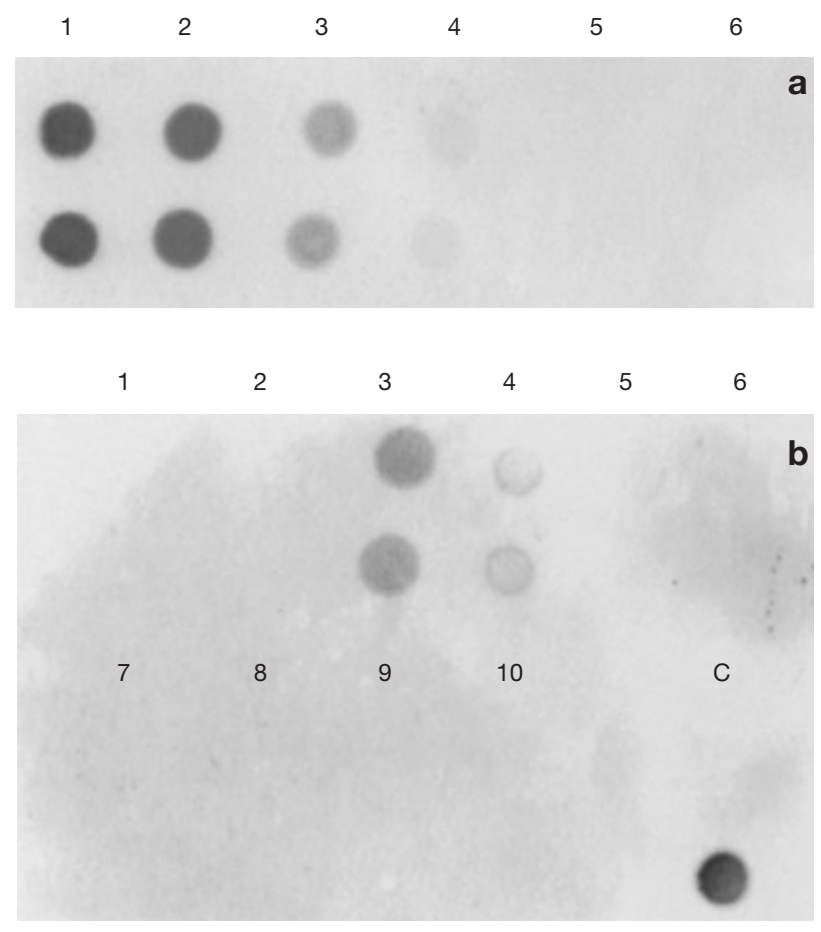

Fig. 1. Dot-blot hybridization of extra small virus (XSV). (a) Its sensitivity was established by hybridization using different concentrations of viral RNA, obtained by successive 10-fold dilutions, ranging from $2.5 \mathrm{ng}$ to $25 \mathrm{fg}$ (Lanes 1 to 6). (b) Application to 5 field samples from Martinique and Guadeloupe islands (French West Indies); dot-blotting of total RNA corresponding to the RNA content of 140 and $14 \mu \mathrm{g}$ of tissue; samples tested: I-h (Lanes 1 and 2), I-j (Lanes 3 and 4), G-c (Lanes 5 and 6), M-1 (Lanes 7 and 8) and M-3 (Lanes 9 and 10). The top and bottom rows are sample replicates. c: Hybridization of a cloned part of XSV genome used as positive control
Knowing the sensitivity of the reaction, the hybridization was then applied to 5 samples collected from Guadeloupe or Martinique. For each sample, hybridization was carried out on 2 amounts of total RNA extracted from tissues or whole animal, and corresponding, respectively, to the RNA content of 140 and $14 \mu \mathrm{g}$ of tissue. Of the 5 samples probed, only 1 was positive (Fig. 1b, Lanes 3 and 4). In this experiment, the negative results may have been because the prawns were not infected or because the viral RNA content of the samples was below detection limits.

\section{RT-PCR}

A feasibility study was carried out using Primer Pair 1 or 2, and 15 ng of viral RNA as template. Results show that Pairs 1 and 2 gave rise to DNA fragments of the expected size, i.e. ca. 0.5 and $0.4 \mathrm{~kb}$, respectively (Fig. 2a, Lanes 1 and 2). This experiment also showed that no other parts of the viral genome of different size were amplified. In further experiments, only Pair 1 was used.

In order to establish the detection limit of RT-PCR, reactions were carried out using different amounts of viral RNA prepared by making successive 10-fold dilutions from $10 \mathrm{ng}$ (Dilution 1) to $0.1 \mathrm{fg}$ (Dilution 9). RT-PCR was able to detect up to $10 \mathrm{fg}$ of viral RNA (Fig. 2.b). As only half of the reaction product was analyzed, the detection limit was $5 \mathrm{fg}$ of viral RNA. Therefore, RT-PCR was 500 times more sensitive than the hybridization method.

The next experiment was conducted to evaluate the sensitivity of the method when applied to presumptively diseased animals. Using successive 10-fold dilutions of total RNA extracted from an infected PL, with the original tissue weight ranging from $1.5 \mathrm{mg}$ to $0.15 \mathrm{ng}$, the RT-PCR proved to be sensitive (Fig. 2c). The amplified DNA fragment of ca. $0.5 \mathrm{~kb}$ was still observed in the dilution corresponding to $15 \mathrm{ng}$ of tissue. The intensity of the band was equivalent to that observed with $5 \mathrm{fg}$ of viral RNA as a template (Fig. 2b). This experiment also indicated that the sample analyzed was highly infected, and that minute amounts of tissue were sufficient for virus detection.

The following experiment was the application of RTPCR to 5 field samples collected in Guadeloupe and Martinique which had already been tested with dotblot hybridization. Reactions were performed on total RNA extracted from tissues weighting 1.4 to $0.14 \mathrm{mg}$. Two were positive for XSV (Fig. 2d: Lanes 7 to 10). Thus, RT-PCR discriminated between XSV-infected and non-infected individuals. It is worthwhile mentioning that except for Sample G-c, all samples were diagnosed with WTD on the basis of clinical observation. XSV was reported to be associated with $M r N V$ in 


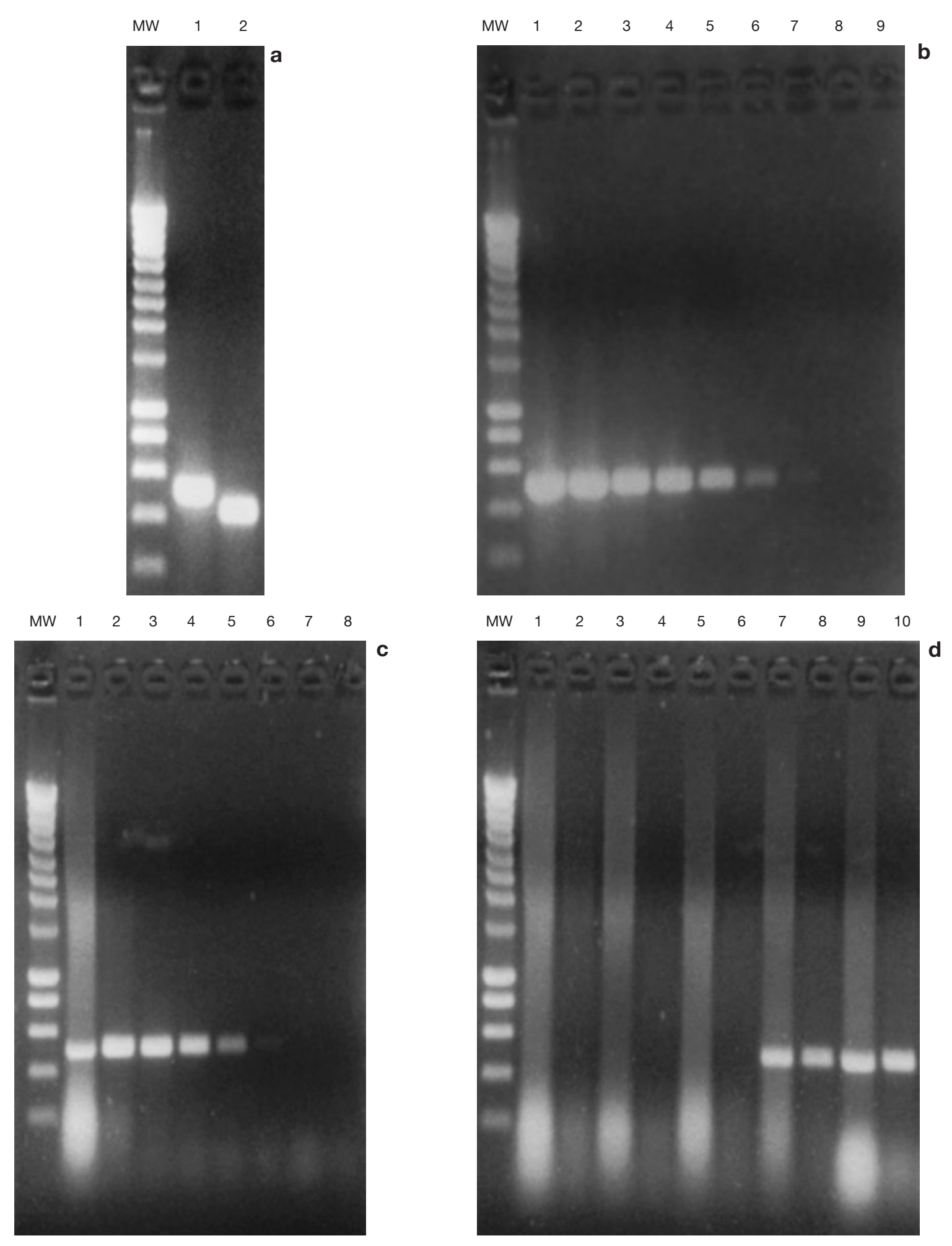

Fig. 2. Detection of extra small virus (XSV) in Macrobrachium rosenbergii by RT-PCR. (a) Trial experiments, using 15 ng viral RNA as template: testing Primer Pair 1, 2 (Lanes 1 and 2, respectively). (b) Evaluation of the detection threshold, using Primer Pair 1 and with viral RNA ranging from $10 \mathrm{ng}$ to $0.1 \mathrm{fg}$ obtained by successive 10 -fold dilutions (Lanes 1 to 9). (c) Quantification of viral particles in a white tail disease (WTD)-affected prawns using different amounts of total RNA obtained by successive 10-fold dilutions ranging from $1.5 \mathrm{mg}$ to $0.15 \mathrm{ng}$ tissue (Lanes 1 to 8). (d) Application on total RNA of 5 field samples from Martinique and Guadeloupe islands (French West Indies), corresponding to the RNA content of 1.4 and 0.14 mg tissue from samples: M-1 (Lanes 1 and 2), M-3 (Lanes 3 and 4), G-c (Lanes 5 and 6), I-h (Lanes 7 and 8) and I-j (Lanes 9 and 10). MW: molecular weight markers 
Table 1. Macrobrachium rosenbergii. RT-PCR analysis of field samples collected in China, showing a clear positive response $(+++)$, positive response $(++$ or +$)$, negative response $(-)$

\begin{tabular}{|ccc|}
\hline $\begin{array}{c}\text { Sample } \\
\text { number }\end{array}$ & $\begin{array}{c}\text { Whitish } \\
\text { coloration }\end{array}$ & RT-PCR \\
\hline 1 & +++ & - \\
2 & + & +++ \\
3 & - & - \\
4 & +++ & - \\
5 & - & - \\
6 & + & - \\
7 & ++ & + \\
8 & - & - \\
9 & +++ & - \\
10 & + & - \\
11 & - & - \\
12 & +++ & - \\
13 & - & ++ \\
14 & +++ & +++ \\
15 & ++ & +++ \\
16 & ++ & + \\
17 & +++ & - \\
18 & +++ & \\
\hline
\end{tabular}

WTD (Qian et al. 2003). However no study has been carried out to establish the involvement of each virus in the disease. Although the characteristic whitish coloration of the tail was clearly observed in Samples M-1 and M-3, and the presence of MrNV was undoubtedly established by dot-blot hybridization and RT-PCR (Sri Widada et al. 2003), these samples were negative for the presence of XSV. The same result was obtained when dot-blot hybridization was used (Fig. 1b). This raises the question of whether all WTD-affected animals are infected by XSV. In order to unravel this problem, RT-PCR was applied to samples collected in hatcheries in China. Individual prawns with WTD were diagnosed according to the whitish coloration of their tail. Not all those positively diagnosed were positive for XSV (Table 1). Some (Samples 1, 4, 9, 12, 14, 18) were XSV-negative, whilst the occurrence of MrNV in these samples was shown (Sri Widada et al. 2003). On the other hand, other samples (Samples 2, $13,15,16)$ showing no clinical signs, or very slight clinical signs of WTD, were positive for XSV. The presence

Editorial responsibility: Timothy Flegel, Bangkok, Thailand of $M r N V$ was detected in Samples 13, 15 and 16 (Sri Widada et al. 2003). Finally, despite the ability of RNA viruses to mutate, application of RT-PCR to samples from China indicated that the primers used allowed the detection of XSV from the 2 hemispheres (West Indies and China).

Analyses of XSV occurrence in prawns affected by WTD indicated that the cause of WTD appears to be more complex than previously thought. The occurrence of $M r N V$ and XSV in diseased animals may be fortuitous, but we have observed the presence of both viruses in the same cell (unpubl. result). A negative response in a sample may also result from the limit of the detection method, and in some cases only a minute amount of one of the partners may be present. More epidemiological surveys are required to better understand the disease. Investigations are currently being carried out to understand the interactions of $\mathrm{MrNV}$ and XSV and their respective roles in WTD of Macrobrachium rosenbergii.

Acknowledgements. This work was partly funded by a grant from the 'Région Martinique'.

\section{LITERATURE CITED}

Arcier JM, Herman F, Lightner DV, Redman RM, Mari J, Bonami JR (1999) A viral disease associated with mortalities in hatchery-reared postlarvae of the giant freshwater prawn Macrobrachium rosenbergii. Dis Aquat Org 38:177-181

Qian D, Shi Z, Zhang S, Cao Z and 5 others (2003) Extra small virus-like particles (XSV) and Nodavirus associated with whitish muscle disease in the giant fresh water prawn Macrobrachium rosenbergii. J Fish Dis 26:521-527

Romestand B, Bonami JR (2003) A sandwich enzyme linked immunosorbed assay (S. ELISA) for detection of $M r N V$ in the giant freshwater prawn Macrobrachium rosenbergii. J Fish Dis 26:71-75

Sri Widada J, Durand S, Cambournac I, Qian D, Shi Z, Dejonghe E, Richard V, Bonami JR (2003) Genome-based detection methods of Macrobrachium rosenbergii nodavirus, a pathogen of the giant freshwater prawn, Macrobrachium rosenbergii dot-blot, in situ hybridization and RT-PCR. J Fish Dis 26:583-590

Tung CW, Wang CS, Chen SN (1999) Histological and electron microscopy study on Macrobrachium muscle virus (MMV) infection in the giant freshwater prawn, Macrobrachium rosenbergii (de Man), cultured in Taiwan. J Fish Dis 22:319-323

Submitted: July 17, 2003; Accepted: October 31, 2003

Proofs received from author(s): January 9, 2004 